\title{
Sustainability Assessment of High Voltage Transmission Lines
}

\author{
Paula Ferreira ${ }^{1 \text { [0000-0002-3712-4803] }}$, Glaucivan da Cunha², Madalena Araújo ${ }^{1 \text { [0000-0002-3515- }}$ \\ 0135] \\ ${ }^{1}$ ALGORITMI Research Centre, University of Minho, Campus Azurém, 4800-058 Guimarães, \\ Portugal \\ ${ }^{2}$ Coordination of Electrical Engineering, FAMETRO- Faculdade Metropolitana de Manaus, \\ Brazil
}

\begin{abstract}
This work aims to contribute to the proposal of a multi-criteria based methodology for sustainability evaluation of impacts from high voltage transmission lines integrating indicators reflecting environmental and socio-economic criteria. The proposed methodology was applied to a transmission grid project in Manaus/Amazonas, Brazil, evaluating its sustainability. From the analysis, it can be observed that the implementation of the project tends to have a significant impact during the construction phase. The most important indexes come from the environmental dimension resulting from a proximity to environmental protected areas and reduction of vegetation both during implementation and operation phases, which is particularly important for the case of Amazonia forest. As for the socio-economic index, this reflects an optimistic expectation of the population towards the arrival of electricity to communities that can lead to the creation of more jobs and improvement of cities infrastructures along with the low expected impact on local protected communities, given the previous studies addressing these concerns during the design phase. Based on the results achieved, avenues for future research are proposed.
\end{abstract}

Keywords: Transmission line, Impact evaluation, Sustainability

\section{Introduction}

The analysis of future electricity needs for different economic agents and society, represents the technical priority for the planning of the electricity sector in Brazil. The definition of the transmission layout is part of this planning requiring the identification of the impacts related to the construction and operation of electricity transmission projects, targeting its minimization and the mitigation of negative effects to the population and to the environment.

Sustainability evaluation can be understood as a multi-criteria problem that should include technical, economic, environmental and social aspects. This way, multi-criteria techniques have been applied for the evaluation of impacts of complex problems such 
as the expansion of the electric system including production, transmission and distribution. In the case of ecological impacts, which are still the major focus of sustainability evaluation, the situation is particularly complex, as the electricity transmission lines can have negative and positive impacts. However, the perception of negative impacts on the environment prevails among residents as is the case of visual pollution [1]. Positive aspects were associated with the perception that electricity transmission lines are necessary for modern life with gains of a socioeconomic nature [2]. Analyzing environmental, economic and social sustainability of the electricity projects along the whole value chain, will open the routes to reach social responsibility for the entire electricity system. As [3] highlighted energy use and availability are central issues in sustainable development. Participatory approaches and policy formulation at the local level can also facilitate these discussions, providing a valuable approach to understanding perceptions and possible conflicts over electricity transmission lines [4]. However, the studies related to the sustainability assessment of high voltage projects are still scarce, particularly in the case of Brazil. Given the expected development of the transmission grid for the next few years in the country [5] it becomes thus highly relevant to address this issue. It is then required to perform a detailed analysis of such large projects that are expected to have a major impact on the economic development of the local populations, having also positive impacts on the overall costs of the Brazilian electrical system.

This work addresses the segment of transmission grids aiming to contribute to demonstrate the use of a methodology for the evaluation of impacts integrating indicators reflecting environmental and socio-economic criteria. High Voltage (HV) grids $(500 \mathrm{kV})$ are extensive and cover large portions of land with different characteristics resulting in significant impacts from the use of the land, from the intrusion caused by the required infrastructures and foundations and even for the opening of new roads and increasing traffic during the construction phase.

. The proposed methodology was applied to evaluate the sustainability of the transmission grid project $500 \mathrm{kV}$ Tucuruí -Manaus: Lot C, SE Oriximiná (Oriximiná / Pará) - SE Cariri (Manaus / Amazonas). The electricity system in Amazonia is the only noninterconnected one in Brazil and the size of the region represents a major challenge for its modernization. These characteristics demonstrate the relevance of the transmission line for the region and for the communities, but also put in evidence the importance of evaluating impacts and mitigate negative social and environmental effects.

The structure of the paper is as follows. Section 2 addresses the electrical system of Manaus, given the focus of the paper on this region. Section 3 presents the methodology for analyzing the sustainability of the transmission line project. In Section 4 the results are described. The main conclusions are summarized at the end.

\section{$2 \quad$ Electrical System of Manaus}

The state of Amazonas, despite having great hydroelectric potential, has always had difficulties in the supply of electricity, despite the permanent contribution of government investments. The long distance of the large consumer centers has contributed to 
the situation, forcing the exploitation of the isolated own generation, supplied in almost $90 \%$ by thermal generation in the capital, Manaus, and $10 \%$ by hydraulic generation.

The Amazonian electrical system is the only one in the country totally unconnected, where the extension of the region seems to multiply the challenges to make it part of the modern world. The development of the transmission grid is then considered an essential step to reach universalization of the access to electric energy in Brazil, along with renewable decentralized power generation [6].

The Tucuruí - Macapá - Manaus interconnection project was established on the Brazilian Transmission Expansion Program - PET 2008 to 2012. The Ministry of Mines and Energy - MME was responsible for the preparation of studies and planning of the project, through the Energy Research Company - EPE [7]. The Tucuruí Interconnection - Macapá - Manaus has a total extension of $1811 \mathrm{~km}$ and crosses 29 municipalities in 3 Brazilian States, namely Amapá, Pará and Amazonas. It was auctioned on June 27, 2008 [8] and the bidding of the project took place in three lots (A, B and C), thus increasing the attractiveness and reducing the risks to the investors. The integration of the Amazon state on the Intergated Electricity System through Tucuruí - Macapá - Manaus line occurred in June 2013 [9].

Figure 1 presents a map of Brazil highlighting the three states crossed by the transmission line and Figure 2 shows a scheme of the 3 lots considered. At an initial design stage different alternatives for the route and layout of the line were analyzed taking into account expected environmental impacts and effect on local population which allowed to select the preferential layout described in Figure 2 [10].

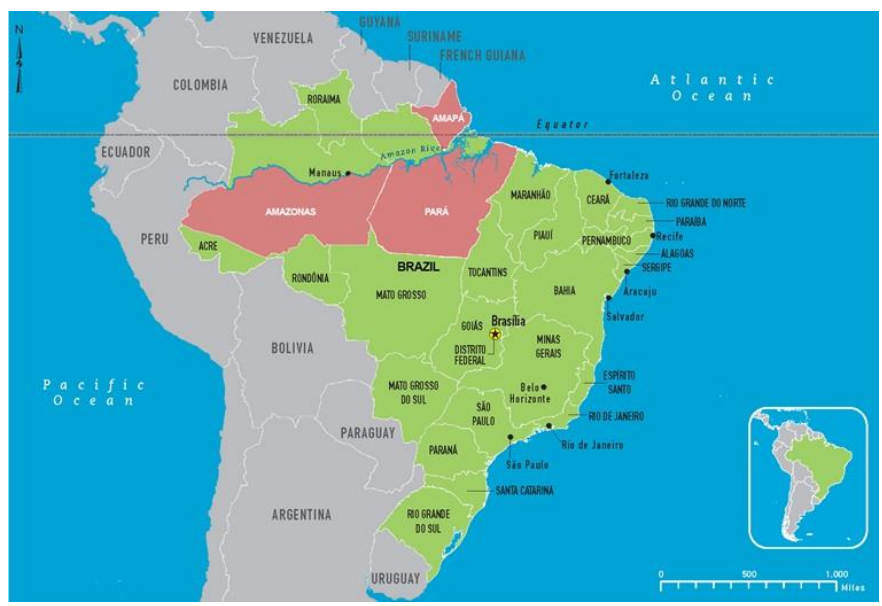

Fig. 1. States crossed by Tucuruí - Macapá - Manaus transmission line. 


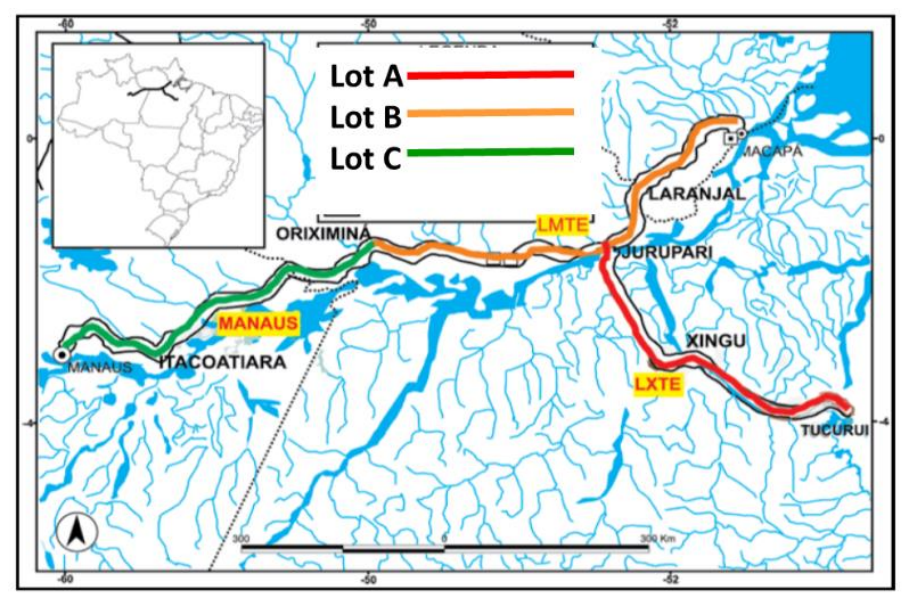

Fig. 2. Schematic representation of the 3 lots of the Tucuruí - Macapá - Manaus transmission line [10].

The study presented in this paper focuses on the analysis of the Oriximiná-Cariri transmission line (Lot C), which will be the one ensuring the connection of the capital of the State of Amazonas to the Brazilian electricity grid.

The $500 \mathrm{~km}$ Oriximiná Cariri (Lot C) transmission line will pass through the states of Pará and Amazonas, along the left bank of the Amazon River, passing through 12 municipalities: 3 of them located in Pará (Oriximiná, Terra Santa and Faro) and 9 of them located in Amazonas (Nhamundá, Parintins, Urucará, São Sebastião do Uatumã, Itapiranga , Silves, Itacoatiara, Rio Preta da Eva and Manaus) [10].

The justification for the construction of the $500 \mathrm{kV}$ line Tucuruí - Macapá - Manaus is based on different studies considering different aspects [10].

- interconnection of the isolated systems of Manaus and Macapá to the Brazilian transmission network;

- possibility of replacing the oil-based thermal generation of existing systems in these cities with a reduction in the associated negative environmental impacts;

- possibility of increasing sustainable regional development;

- contribution to improving the quality of life of the population to be served.

\section{$3 \quad$ Methodology}

With the ultimate objective of analyzing the sustainability of the Tucuruí-Manaus transmission line project in relation to economic, environmental and social factors, the following specific research steps were defined:

- Investigate and characterize the Tucuruí-Manaus transmission line project;

- Investigate and select a set of social, environmental and economic criteria and indicators for the evaluation of transmission line projects; 
- Evaluate the line design of $500 \mathrm{kV}$ Tucuruí -Manaus (Lot C) in accordance with the selected criteria.

The process of evaluating the sustainability of a transmission project should aim to provide information on the set of impacts or interferences caused by the transmission system including transmission line and substations. In the evaluation of sustainability, there are usually methods that allow for the association of several indicators with their respective dimensions (e.g. social, economic, environmental, cultural). Sustainability is thus perceived as a multi-criteria problem, which should include widely accepted technical, economic, and environmental assessment criteria allowing to evaluate both the positive impact and the negative impact of the enterprise.

In this work, the methodology proposed in the Technical Note DEA - 21/10 [11] for the sustainability evaluation of hydroelectric power plants and HV transmission lines was followed. Based on sustainability criteria and considering that the indicators should necessarily comprise the evaluation of both the positive impacts and the negative impacts caused, a list of indicators was then defined to make up the sustainability index. This list has been reduced according to the availability of information, its accuracy and relevance for the case of HV transmission lined. According to the EPE [11], 11 indicators were then defined, six of them in the environmental dimension and five in the socioeconomic dimension, as presented in Table 1.

As different scales are used for each criterion their conversion in a common scale was required. The approach proposed by [12] was used and the conversion was then based on a simple ratio as indicated by equation (1) for positive impacts and by equation (2) for negative impacts.

$$
\begin{aligned}
& \mathrm{I}=(\mathrm{x}-\mathrm{m}) /(\mathrm{M}-\mathrm{m}) \\
& \mathrm{I}=(\mathrm{M}-\mathrm{x}) /(\mathrm{M}-\mathrm{m})
\end{aligned}
$$

where $\mathrm{I}$ is the value of the index (0-1 scale) to be calculated, $\mathrm{x}$ is the value obtained in the initial scale, $m$ is the minimum value and $M$ is the maximum value. As such each indicator represents the sustainability index of the project comparatively to the worst possible situation, with $\mathrm{I}=0$ representing the worst possible case (minimum sustainability) and $\mathrm{I}=1$ representing the best possible case (maximum sustainability).

Each one of the dimensions is then computed by calculating a simple arithmetic mean of all corresponding indicators, from which a classification is derived. Given the scarcity of information in what concerns impact assessment for transmission grids, the model assumes the independence of each indicator and equal weights assigned to each of them following the insufficient reason Principle (interested readers can see the principle [13]) and also the [11] proposal. 
Table 1. Environmental and Socioeconomic Dimension (Source: Adapted from [11)

\begin{tabular}{|c|c|c|c|}
\hline Dimension & Indicator & Notes & Description \\
\hline \multirow[t]{6}{*}{$\begin{array}{l}\text { Environmen- } \\
\text { tal }\end{array}$} & $\begin{array}{l}\text { Corridor exten- } \\
\text { sion }\end{array}$ & $\begin{array}{l}\text { Related to the required land for LT } \\
\text { use } \\
\text { Land use factor }\end{array}$ & Corridor extension $(\mathrm{km})$ \\
\hline & $\begin{array}{l}\text { Presence and / } \\
\text { or proximity to } \\
\text { protected areas } \\
\text { (PA) } \\
\text { in the HV cor- } \\
\text { ridor }\end{array}$ & $\begin{array}{l}\text { PA include lands and regions for } \\
\text { which the natural conditions require } \\
\text { special protection measures } \\
\text { Biodiversity factor }\end{array}$ & $\begin{array}{l}\text { Identification and posi- } \\
\text { tioning of PA near or } \\
\text { within the corridor by PA } \\
\text { category }(\%)\end{array}$ \\
\hline & $\begin{array}{l}\text { Presence of bi- } \\
\text { odiversity pro- } \\
\text { tection areas } \\
\text { (BPA) in the } \\
\text { corridor }\end{array}$ & $\begin{array}{l}\text { BPA include lands and regions which } \\
\text { can become in the future PA } \\
\text { Biodiversity factor }\end{array}$ & $\begin{array}{l}\text { Identification and posi- } \\
\text { tioning of BPA in the cor- } \\
\text { ridor }\left(\mathrm{km}^{2}\right)\end{array}$ \\
\hline & $\begin{array}{l}\text { Presence of } \\
\text { forest areas } \\
\text { in the corridor }\end{array}$ & $\begin{array}{l}\text { Potential for deforestation } \\
\text { Biodiversity factor }\end{array}$ & $\begin{array}{l}\text { Identification and quanti- } \\
\text { fication of the forest areas } \\
\text { in the corridor }\left(\mathrm{km}^{2}\right)\end{array}$ \\
\hline & $\begin{array}{l}\text { Presence of } \\
\text { secondary veg- } \\
\text { etation areas in } \\
\text { the corridor }\end{array}$ & $\begin{array}{l}\text { Potential negative effects over local } \\
\text { vegetation } \\
\text { Biodiversity factor }\end{array}$ & $\begin{array}{l}\text { Identification and quanti- } \\
\text { fication of secondary veg- } \\
\text { etation areas in the corri- } \\
\text { dor }\left(\mathrm{km}^{2}\right)\end{array}$ \\
\hline & $\begin{array}{l}\text { Presence of sa- } \\
\text { vannah and / or } \\
\text { steppe areas in } \\
\text { the corridor }\end{array}$ & $\begin{array}{l}\text { Potential negative effects over sa- } \\
\text { vanna and steppe areas } \\
\text { Biodiversity factor }\end{array}$ & $\begin{array}{l}\text { Identification and quanti- } \\
\text { fication of savanna areas } \\
\text { in the corridor }\left(\mathrm{km}^{2}\right)\end{array}$ \\
\hline \multirow[t]{5}{*}{$\begin{array}{l}\text { Socio-eco- } \\
\text { nomic }\end{array}$} & $\begin{array}{l}\text { Presence and / } \\
\text { or proximity of } \\
\text { Indigenous } \\
\text { Land (s) in the } \\
\text { corridor }\end{array}$ & $\begin{array}{l}\text { Living conditions factor/Protection } \\
\text { of vulnerable population }\end{array}$ & $\begin{array}{l}\text { Identification and dis- } \\
\text { tance to Indigenous Lands } \\
\text { near or within the corridor } \\
(\mathrm{km})\end{array}$ \\
\hline & $\begin{array}{l}\text { Presence of } \\
\text { classified/pro- } \\
\text { tected rural } \\
\text { land (s) in the } \\
\text { corridor } \\
\end{array}$ & $\begin{array}{l}\text { Living conditions factor/ Protection } \\
\text { of vulnerable population }\end{array}$ & $\begin{array}{l}\text { Identification and dis- } \\
\text { tance to the classified ru- } \\
\text { ral lands in the corridor } \\
(\mathrm{km})\end{array}$ \\
\hline & $\begin{array}{l}\text { Presence of ur- } \\
\text { ban areas in the } \\
\text { corridor }\end{array}$ & Living conditions factor & $\begin{array}{l}\text { Identification and quanti- } \\
\text { fication of urban areas in } \\
\text { the corridor }(\%)\end{array}$ \\
\hline & $\begin{array}{l}\text { Presence of ag- } \\
\text { riculture and } \\
\text { forestry areas } \\
\text { in the corridor }\end{array}$ & Living conditions factor & $\begin{array}{l}\text { Identification and quanti- } \\
\text { fication of areas of agri- } \\
\text { cultural and forestry areas } \\
\text { in the corridor }\left(\mathrm{km}^{2}\right)\end{array}$ \\
\hline & $\begin{array}{l}\text { Direct jobs to } \\
\text { be generated in } \\
\text { the line deploy- } \\
\text { ment phase }\end{array}$ & Living conditions factor & $\begin{array}{l}\text { Number of direct jobs to } \\
\text { be generated in the line } \\
\text { deployment phase }\end{array}$ \\
\hline
\end{tabular}

The HV sustainability indicator (I) assumes values between "0" and "1", assigning to "0" - "Very low sustainability" and to value "1" - "Very high sustainability", as shown in Table 2. 
Table 2. Classification of Sustainability Indicators (Source: Adapted from [11)

\begin{tabular}{ll}
\hline Indicator (I) & Ranking \\
\hline I $<0.2$ & Very low \\
$0.2<$ I $<0.4$ & Low \\
$0.4<$ I $<0.6$ & Average \\
$0.6<$ I $<0.8$ & High \\
$0.8<$ I $<1.0$ & Very high \\
\hline
\end{tabular}

The criteria used to select the indicators were not limited to their importance, but considered also the existence of data and the quality of the information in order to be possible a judicious and reliable evaluation [11]. A Global Sustainability Index - GSI was obtained from the aggregation of indices obtained for each dimension, following the approach proposed by [12].

The proposed methodology was applied in the analysis of the sustainability of the $500 \mathrm{kV}$ Tucuruí -Manaus transmission line project : Lot C, SE Oriximiná (Oriximiná / Pará) - SE Cariri (Manaus / Amazonas) and the main results are presented in the following sections.

\section{$4 \quad$ Results}

Table 3 presents the results of the environmental and socio-economic assessment, including the partial values obtained for each indicator and the aggregated environmental indicator (EI) and socio-economic indicator (SEI). Data for each one of the proposed indicators were obtained from [10] for the case of the selected transmission lined. The values were then converted into a dimensionless scale (0-1) obtained from [12] method. In order to obtain the Global Sustainability Index (GSI), the simple arithmetic mean between EI and SEI was calculated.

The results indicate a high sustainability index (GSI) for the transmission line, as follows from the scale proposed in Table 2.

It is observed that the implementation of the transmission line produced greater impacts during its construction phase. The Environmental Index - EI 0.38, reflects a low sustainability level which comes from the combination of several factors, namely the extension of the corridor, the proximity to protected environmental areas and expected high impacts on the vegetation. These results are particularly remarkable given that the region involved is the Amazon rainforest.

Regarding the Socioeconomic Index (ISE), it reached a quite high value of 0.84 which can be classified as very high according to Table 2 . This high value comes mainly from the ensured minimum distance to lands with special classification because of their relation to vulnerable population. In fact, the effect on the reduction of agricultural and forestry areas in the corridor is considered to be low as less than $20 \%$ of these areas will be crossed by the corridor. This corridor is expected also to be more than $10 \mathrm{~km}$ 
away from Indigenous communities and from protected rural land (s) in the corridor, which once again result on high sustainability indicators.

However, it should be highlighted that these values are mainly based on the scale proposed in [11] and if more conservative values were to be considered, the resulting sustainability index can be significantly affected.

Table 3. Environmental and socio-economic assessment

\begin{tabular}{|c|c|c|}
\hline Dimension & Indicator & Value $(0-1)$ \\
\hline \multirow[t]{6}{*}{ Environmental } & Corridor extension & 0.07 \\
\hline & $\begin{array}{l}\text { Presence and / or proximity to protected areas } \\
\text { (PA) in the HV corridor }\end{array}$ & 0.00 \\
\hline & $\begin{array}{l}\text { Presence of biodiversity protection areas (BPA) } \\
\text { in the corridor }\end{array}$ & 0.84 \\
\hline & Presence of forest areas in the corridor & 0.45 \\
\hline & $\begin{array}{l}\text { Presence of secondary vegetation areas in the } \\
\text { corridor }\end{array}$ & 0.00 \\
\hline & $\begin{array}{l}\text { Presence of savannah and / or steppe areas in the } \\
\text { corridor }\end{array}$ & 0.93 \\
\hline EI & Environmental Indicator & 0.38 \\
\hline \multirow[t]{5}{*}{ Socio-economic } & $\begin{array}{l}\text { Presence and / or proximity of Indigenous Land } \\
\text { (s) in the corridor }\end{array}$ & 1.00 \\
\hline & $\begin{array}{l}\text { Presence of classified/protected rural land (s) in } \\
\text { the corridor }\end{array}$ & 1.00 \\
\hline & Presence of urban areas in the corridor & 1.00 \\
\hline & $\begin{array}{l}\text { Presence of agriculture and forestry areas in the } \\
\text { corridor }\end{array}$ & 0.83 \\
\hline & $\begin{array}{l}\text { Direct jobs to be generated in the line deploy- } \\
\text { ment phase }\end{array}$ & 0.36 \\
\hline SEI & Socio-Economic Indicator & 0.84 \\
\hline GSI & Global Sustainability Index & 0.61 \\
\hline
\end{tabular}

\section{Conclusions}

With the implementation of the Tucuruí - Macapá - Manaus transmission line, several benefits can be enumerated: reduction of thermoelectric plants; improvement of the quality of life of the inhabitants, especially those who live in the interior, far from the capital; improvement in electricity supply and promotion of economic development in the city. But there will be major socio-environmental challenges in a region that has a rich biodiversity and the traditional culture of the people of the Amazon.

The advantages obtained from the interconnection of the city of Manaus to the other regions of the country by the National Interconnection System - SIN are significant in the drastic reduction of carbon dioxide released into the atmosphere, elimination of oil spills in rivers and related taxes. But there is the other side of the coin, which are particular remarkable for the case of the environmental aspects. The negative impact of "suppression of native vegetation" and the positive impact of "supplying electric power to communities" are highlighted as being of a high degree of significance. 
The achieved Global Sustainability Index classified as High (GSI - 0.61), reflects the balance between the socio-economic and the environmental aspects and results also from the pre-selection stage for the layout of the line which already took into account these sustainability concerns. Even so, from the analysis it can be observed that the implementation of this portion of the line (Lot C) led to a significant impact during the construction phase. The most important negative indexes come from the environmental dimension as results of the reduction of vegetation both during implementation and operation phases. Recognizing that sustainability levels should be analyzed taking into account the region, and considering that this case includes the sensitive region and biome of Amazonia forest, the question of vegetation turns to be particularly important.

This research opens important avenues for future research on the need to adapt the methodology to the specificities of the region under analysis. As for the socio-economic index, the results reflect an optimistic expectation of the population towards the arrival of electricity to communities which can lead to the creation of more jobs and improvement of cities infrastructures. However, some concerns about the impact on the availability of rural lands to be used mainly for agriculture purpose in the region should also be highlighted.

From the study, it becomes obvious that although a common framework can be envisaged, sustainability evaluation must reflect the characteristics of each case under analysis. The proper selection of specific indicators relevant for the case is required along with the definition of a well-suited scale, for the final integration in an overall index for which different weights may be considered. In this study, and for the sake of simplicity, equal weights were assumed for each factor. Future work may address weight differentiation or may even consider a change on the structure of the problem using a more complex multi-criteria model able to deal with different scales and weights.

\section{Acknowledgement}

This work is financed by the ERDF - European Regional Development Fund through the Operational Programme for Competitiveness and Internationalisation COMPETE 2020 Programme, and by National Funds through the Portuguese funding agency, FCT Fundação para a Ciência e a Tecnologia, within project SAICTPAC/0004/2015-POCI/01/0145/FEDER/016434.as well as by the ALGORITMI research Centre POCI-01-0145-FEDER-007043 and FCT - Fundação para a Ciência e Tecnologia within the Project Scope: UID/CEC/00319/2013.

\section{$7 \quad$ References}

[1] Kaltenborn, B., Bjerke, T.: Associations between environmental value orientations and landscape preference. Landscape Urban Plan 59, 1-11 (2002).

[2] Soini, K.,Pouta, E., Salmiovirta, M., Usitalo, M. \& Kivinen, T.: Local residents' perceptions of energy landscape: the case of transmission line. Land Policy 28, 294-305 (2011).

[3] Ferreira, P., Araújo, M. \& O’Kelly, M.E.J.: The integration of social concerns into electricity 
power planning: A combined Delphi and AHP approach. In: Rebennack, S., Pardalos, P.M., Pereira, M.V.F., Iliadis, N.A. (Eds.) Handbook of Power Systems, pp. 323-364. Spinger (2010).

[4] Soini, K., Aakkula, J.: Framing the biodiversity of agricultural landscape: the essence of local conceptions and constructions. Land Use Policy 24, 311-321 (2007).

[5] EPE - Empresa de Pesquisa Energética: Plano Decenal de Expansão de Energia 2026 -PDE 2026. July 2017, Ministério de Minas e Energia, Rio de Janeiro (2017).

[6] Pereira, M.G., Freitas, M.A.V. \& da Silva, N.F.: Rural electrification and energy poverty: Empirical evidences from Brazil, Renewable and Sustainable Energy Reviews 14(4), 1229-1240 (2010).

[7] EPE - Empresa de Pesquisa Energética. Estudos para licitação da expansão da transmissão. Consolidação das analyes e pareceres técnicos. Programa de Expansão da Transmissão PET 2008-2012. January 2008, Ministério de Minas e Energia, Rio de Janeiro (2008).

[8] ANEEL. Edital 004/2008, de março de 2008. March 2008 (2008).

[9] ONS. Necessidade de permanência das usinas térmicas de Manaus em 2015, Nota Técnica 0011/2015. January 2015, Rio de Janeiro (2015).

[10] Biodinâmica Rio. Relatório de Impacto Ambiental/Rima - Linha de Transmissão 500 kV Oriximiná-Cariri. June 2009, Rio de Janeiro (2009).

[11] EPE - Empresa de Pesquisa Energética: Metodologia para avaliação da Sustentabilidade socioeconômica e ambiental de UHE e LT, Série Estudos do Meio Ambiente, Nota Técnica DEA 21/10. November 2010, Ministério de Minas e Energia, Rio de Janeiro (2010).

[12] Martins, M. F., \& Cândido, G. A.: Índices de desenvolvimento sustentável para localidades: uma proposta metodológica de construção e análise. Revista de Gestão Social e Ambiental 6(1), 3-19. (2012).

[13] Sinn, H.-W.: A rehabilitation of the principle of insufficient reason. The Quarterly Journal of Economics 94 (3), 493-506 (1980). 